\title{
Redaksioneel
}

\section{Bedreigde insekte: 'n Gebrek aan kennis?}

Bedreigde insekspesies kry gelukkig 'n toenemende mate van aandag in Suid-Afrika, aangesien sowel die publiek as natuurbewaringsinstansies al hoe meer bewus raak van insekte en hulle ekologiese belang. Natuurbewaringsinstansies begin hulle te beywer vir wetgewing om insekte te beskerm en studies word selfs onderneem om vas te stel watter spesies bedreig word. Die International Union for Conservation of Nature (IUCN) is tans besig om 'n lys bedreigde insekspesies saam te stel. Onlangs het 'n skoenlapperspesie heelwat publisiteit gekry omdat dit deur stedelike uitbreiding op die Witwatersrand bedreig word. Met ons huidige kennis kan ons egter nie eers selfs 'n aanduiding kry van hoeveel insekspesies werklik bedreig word en die redes daarvoor nie. Die beskermingstrategieë is lofwaardig, maar in baie gevalle is dit 'n kwessie van die kar voor die perd span. Ons moet eers heelwat van die bedreigde insek weet voordat doeltreffende en realistiese beskermingsmaatreëls ingestel kan word. Indien die idee is om ons omgewing te bewaar, moet ons eers kennis dra van die kritiese eienskappe of faktore wat vir die oorlewing van die insek noodsaaklik is. Dit is onmoontlik om 'n spesie te beskerm indien die komponente waaruit sy omgewing saamgestel is, asook die wisselwerking tussen hulle, nog onbekend is.

Watter spesies in Suid-Afrika bedreig word, is nog 'n suiwer akademiese vraag. Ek twyfel sterk daaraan of daar voldoende kennis van 'n enkele spesie is om die kritiese komponente van sy omgewing te bepaal. $\mathrm{Ek}$ is oortuig daarvan dat algemeen aanvaar word dat unieke gebiede beskerm moet word om daardeur te verseker dat die spesies wat daar voorkom wel sal oorleef. Verder sal almal waarskynlik saamstem met die aanname dat insekspesies hoofsaaklik deur die vernietiging van hulle habitat bedreig word. Gevolglik, indien ons aanvaar dat ons nie 'n spesie kan beskerm as die komponente van sy omgewing nog onbekend is nie, is dit ook waar om te sê dat ons nie ons omgewing kan beskerm as ons nie sy komponente en hulle interaksie ken nie. Dit kom dus voor of daar sowel min bekend is oor bedreigde spesies as oor hoe om hulle te beskerm. Dit is natuurlik geensins die geval nie.

In vergelyking met ander diere en plante, is insekte nog baie swak bestudeer en daar is feitlik niks bekend omtrent resent uitgestorwe soorte nie. In die laaste 50 jaar het 76 gewerwelde spesies uitgesterf. Tans word 276 soogdierspesies, 345 voëls, 136 amfibieërs en reptiele, 99 vis- en 20000 plantespesies bedreig. ' Dit is nog slegs die punt van die ysberg, want insekte maak $75 \%$ van alle diersoorte uit, en ons weet nog bloedweinig van hulle. Meer as een miljoen is wel aan die wetenskap bekend. Volgens ' $n$ onlangse beraming van insekgetalle in Suid-Afrika, ${ }^{2}$ is ongeveer 80000 spesies hier bekend of benaam. Daar word bereken dat dit maar net $5 \%$ tot $30 \%$ van die werklike getal spesies verteenwoordig. Hierdie vae skatting is dan ook ' $n$ direkte aanduiding van ons gebrekkige kennis van ons insekfauna. Slegs ongeveer 20 professionele entomoloe is aktief betrokke by die versameling en beskrywing van nuwe spesies in hierdie land, en hierdie navorsingsrigting, taksonomie, vorm letterlik die hoeksteen van dié wetenskap. 'n Onlangse verslag van die $\mathrm{WNNR}^{3}$ het die dringende behoefte aan die studie van insektaksonomie beklemtoon, maar weens gebrek aan voldoende navorsingsfondse en 'n tekort aan mannekrag, sal hierdie probleem heel waarskynlik akuut bly.

Om te praat van die beskerming van insekte in die algemeen, is goed bedoel, maar sinloos, aangesien ons nie iets kan beskerm as ons nie kan bewys dat dit wel bestaan nie. Daar word vermoed, en ook besef, dat sekere spesies bedreig word, maar hulle word bedreig deur die vernietiging of wysiging van hulle habitat. Hiervolgens moet ons die afleiding maak dat die spesies sal oorleef as die habitat bewaar word. Wanneer selfs net ' $n$ deel van die habitat vernietig word, word sy komponente vernietig. Wanneer bewaringsinstansies dus poog om ,,bedreigde" spesies te beskerm, sal hulle beste pogings tot mislukking gedoem wees as hulle nie oor voldoende kennis omtrent die spesies beskik nie. Op hierdie wyse is daar in die verlede waarskynlik baie foute gemaak. Welmenende instansies het probeer om 'n omgewing te bewaar sonder 'n definitiewe werksmetode, asook sonder om hulself af te vra wat hulle besig was om te bewaar en die beste metode om dit te bewerkstellig. Selfs opgeleide bioloë vergeet (of ignoreer) dikwels die enorme aantalle insekte en hulle effek op selfs 'n beperkte area.

Ongelukkig is die posisie in Suid-Afrika (en ook elders in die wêreld) so dat ons die insekfauna eers sal moet bestudeer, selfs al is dit net om hulle te versamel en te benaam, en om hulle op rekord te plaas. Tot dusver het hierdie versamelings dikwels waardevolle inligting verskaf oor die omgewingstoestande van die verlede. Hierdie feit is welbekend in die Entomologie en voorbeelde hiervan is volop. Soos afgelei kan word uit vroeëre versamelings, was sekere waterbewonende insekspesies volop in die suidwestelike Kaapprovinsie tot omtrent 30 jaar gelede. Tans is hulle skaars of selfs heeltemal afwésig. Dit kan moontlik toegeskryf word aan die loslating van forelle, of aan waterbesoedeling, albei per ongeluk of sonder inagneming van die gevolge. As ons van een spesie weet, kan ons die vraag vra hoeveel onbekende spesies al verdwyn het sonder dat ons daarvan bewus was.

Om met gesag oor bedreigde spesies te kan praat, is 
dit noodsaaklik dat ons weet watter spesies in 'n gegewe area voorkom. Hierna moet daar kennis ingewin word oor al die wisselwerkings tussen die insekte en hul omgewing. Met die huidige mannekrag en finansiële ondersteuning tot ons beskikking kan nie eers begin word om selfs die mees fundamentele navorsing oor net 'n klein persentasie van ons insekfauna te doen nie. Die ideaal sou wees om alle omgewings ongeskonde te bewaar om die oorlewing van alle spesies te verseker, maar in 'n ontwikkelende wêreld is dit ' $n$ baie onrealistiese beskouing. ' $n$ Meer realistiese en ook wenslike metode sou wees om inseknavorsing in bedreigde gebiede te loods. Dit sal heelwat insette en baie basiese entomologiese navorsing verg, en in ' $n$ moderne wêreld wat ooglopend meer in die ekonomie as in die estetiese belang stel, is dit twyfelagtig of sinvolle vordering gemaak sal word om die nodige kennis te bekom voordat ons oor die beskerming van insekspesies kan praat of besin.
Die mens se toekoms is ten nouste gekoppel aan die hantering van en belegging in sy omgewing met sy verskeidenheid, maar omdat hy gekniehalter word deur 'n ruimte-tydbeperking en uiteindelik deur geld, is dit twyfelagtig of werklike vordering ooit gemaak sal word in die rigting van ' $n$ beter begrip van bedreigde insekte.

\section{VERWYSINGS}

1. Wilkinson, C. (1982). Systematics and conservation. Ents Gaz. $33,53-67$.

2. Scholtz, C.H. \& Holm, E. (1985). Insects of Southern Africa (Butterworths, Durban) $502 \mathrm{pp}$.

3. Du Plessis, E.P. (1985). Taxonomy in the Republic of South Africa. Report to the National Committee for the International Union of Biological Sciences (CSIR, Pretoria).

\section{C.H. SCHOLTZ}

Departement Entomologie

Universiteit van Pretoria

\section{Navorsingsuitsette aan universiteite}

Die Suid-Afrikaanse Tydskrif vir Natuurwetenskap en Tegnologie van die Suid-Afrikaanse Akademie vir Wetenskap en Kuns is een van die tydskrifte wat kwalifiseer vir navorsingsuitset-subsidie aan universiteite.

Bydraes binne die volgende kategorieë kom vir subsidie in aanmerking:

Navorsingsartikels

Vakwetenskaplike oorsigartikels

Vakboekhoofstukke en Vakboeke

Internasionale patente
Geredigeerde konferensieverrigtinge (net volledige voordragte, nie uitgebreide ekserpte nie)

(Die spesifieke bedrag vir ' $n$ bepaalde begrotingsjaar kan van die individuele universiteitsowerhede verkry word.)

Meer besonderhede kan verkry word van die Voorsitter van die Redaksiekomitee, prof. A. Strasheim, Dept. Chemie, Universiteit van Pretoria, Pretoria (telefoonnommer (012) 420-2096). 